DNA Library of Life, research article

urn:Isid:zoobank.org:pub:EB6AF6D6-36E7-4677-87E8-D72C42A273AF

\title{
Molecular systematics and biogeography of the Hemigalinae civets (Mammalia, Carnivora)
}

\author{
Géraldine VERON ${ }^{1, *}$, Céline BONILLO ${ }^{2}$, \\ Alexandre HASSANIN ${ }^{3}$ \& Andrew P. JENNINGS ${ }^{4}$ \\ 1,3 Institut de Systématique, Evolution, Biodiversité, UMR 7205 ISYEB, \\ CNRS MNHN UPMC EPHE, Muséum national d'Histoire naturelle, \\ Sorbonne Universités, CP 51, 57 rue Cuvier, 75231 Paris Cedex 05, France. \\ ${ }^{2}$ Service de Systématique moléculaire, UMS CNRS 2700, Muséum national d'Histoire naturelle, \\ CP 26, 57 rue Cuvier, 75231 Paris Cedex 05, France. \\ ${ }^{4}$ SMALL CARNIVORES - Research and Conservation, 83 St. Lawrence Street, \\ Portland, 04101 Maine, USA. \\ *Corresponding author: veron@mnhn.fr \\ ${ }^{2}$ Email: bonillo@mnhn.fr \\ ${ }^{3}$ Email: hassanin@mnhn.fr \\ ${ }^{4}$ Email: smallcarnivores@yahoo.com \\ ${ }^{1}$ urn:1sid:zoobank.org:author:DE2A6A51-29F0-4A5E-A60B-C61AD5E1842E \\ ${ }^{2}$ urn:1sid:zoobank.org:author:7333D242-0714-41D7-B2DB-6804F8064B13 \\ ${ }^{3}$ urn:Isid:zoobank.org:author:0DCC3E08-B2BA-4A2C-ADA5-1A256F24DAA1 \\ ${ }^{4}$ urn:Isid:zoobank.org:author:3978AC9E-2C27-4B68-99DA-038B502AFDA8
}

\begin{abstract}
Due to the difficulty in obtaining samples, the systematics of the Hemigalinae civets has not been fully resolved. The aim of this study was to clarify the relationships of the species and the intraspecific diversity within this subfamily, and to explore the environmental factors that might have affected its evolution. Using two mitochondrial and two nuclear markers, we confirmed that the Hemigalinae comprises Owston's civet, the otter civet, Hose's civet and the banded civet, but also the Sulawesi palm civet (formerly included in the Paradoxurinae). Our study showed that the banded and Owston's civets are sister species, and suggested that Hose's civet is sister to these two. Within the banded civet, we observed a high divergence between individuals from the Mentawai Islands and those from Sumatra and Borneo (while the latter two were not strongly divergent), likely due to the deep sea channel between the Mentawai Islands and Sumatra. Unexpectedly, the Sumatran and Peninsular Malaysian individuals were not closely related, despite the fact that these two regions have repeatedly been connected during the last glaciations. No high polymorphism was found within Owston's civet, although three groups were obtained: southern China, northern Vietnam and central Vietnam, which might be related to Pleistocene climatic fluctuations.
\end{abstract}

Keywords. Southeast Asia, phylogeography, civets, Viverridae, molecular systematics.

Veron G., Bonillo C., Hassanin A. \& Jennings A.P. 2017. Molecular systematics and biogeography of the Hemigalinae civets (Mammalia, Carnivora). European Journal of Taxonomy 285: 1-20. http://dx.doi.org/10.5852/ ejt.2017.285 


\section{Introduction}

The subfamily Hemigalinae (Viverridae) comprises four species: Owston's civet Chrotogale owstoni Thomas, 1912, the otter civet Cynogale bennettii Gray, 1837, Hose's civet Diplogale hosei (Thomas, 1892), and the banded civet Hemigalus derbyanus (Gray, 1837), that are found in Southeast Asia and southern China (Jennings \& Veron 2009; Fig. 1). Very little is known about their ecology, but they seem to be nocturnal, mainly terrestrial, and are primarily found in tropical forests (Veron et al. 2006; Jennings \& Veron 2009; Jennings et al. 2013). The banded civet and otter civet occur mainly in the lowlands, while Hose's civet is primarily found at higher elevations (Veron et al. 2006; Jennings et al. 2013); Owston's civet seems to be found both in lowland and montane forests (Jennings \& Veron 2009). These species are of conservation concern, with the otter civet listed as Endangered and the other three as Vulnerable by the IUCN (2015), although there is a scarcity of data about their current population trends and sensitivity to environmental disturbance (Schreiber et al. 1989; Jennings \& Veron 2009; Jennings et al. 2013). The destruction and degradation of tropical forests are clearly major threats to this group (Meijaard \& Sheil 2008; Corlett 2009; Jennings et al. 2013). Despite these threats, little molecular systematics work has been done on this group; knowledge of their phylogenetic diversity, intraspecific genetic diversity and structure, and population differentiation is crucial for defining conservation priorities and for the identification of evolutionarily significant units (ESUs, Ryder 1986; Moritz 1994; Haig 1998; Isaac et al. 2007).

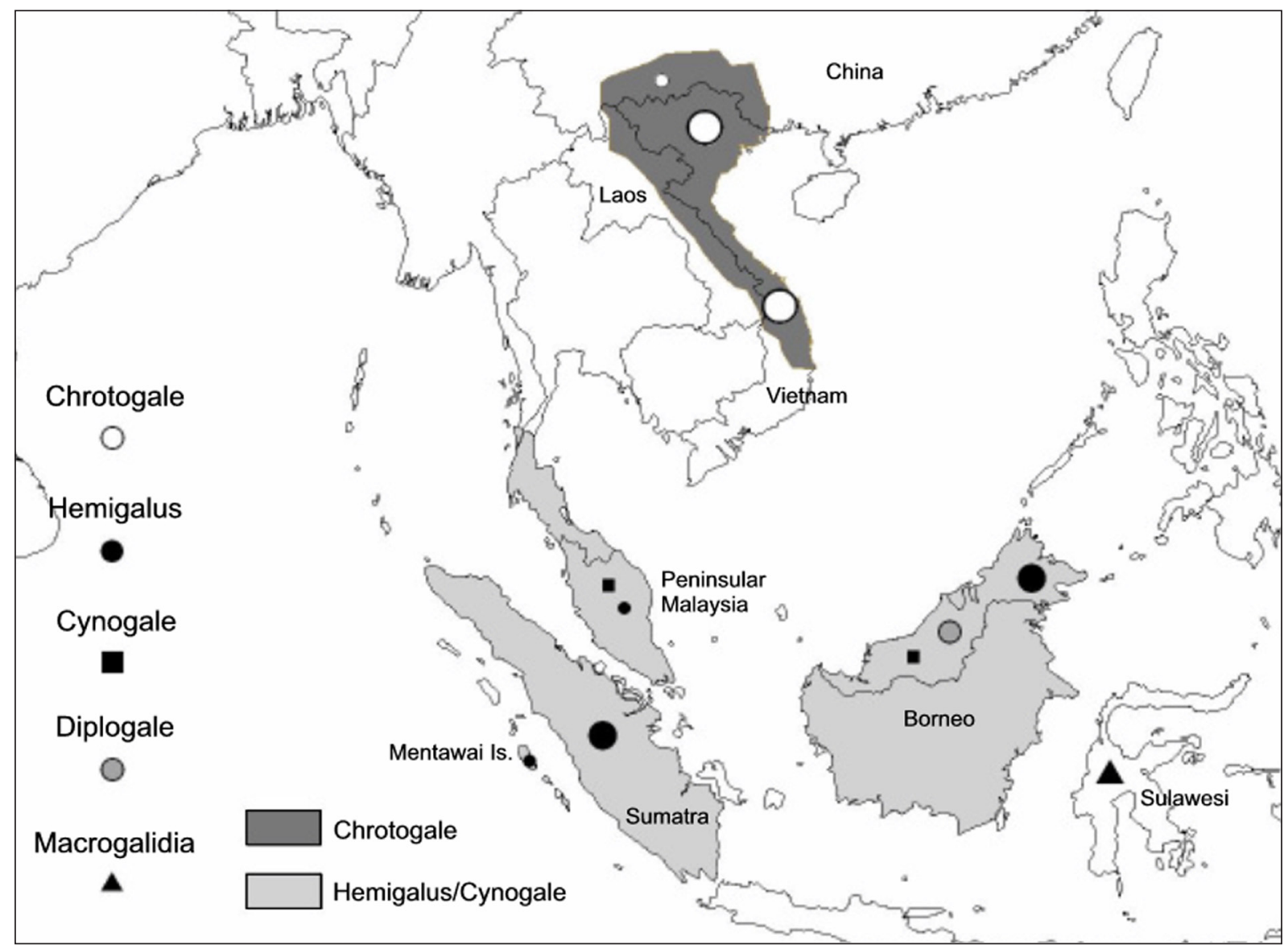

Fig. 1. Map showing the distribution of the samples of Hemigalinae used in this study. The gray shadings show the range of Chrotogale owstoni Thomas, 1912, Cynogale bennettii Gray, 1837 and Hemigalus derbyanus (Gray, 1837); Diplogale hosei (Thomas, 1892) is only found on Borneo and Macrogalidia musschenbroekii (Schlegel, 1879) only occurs on Sulawesi. The size of the sample symbols corresponds to the number of samples from each area (the smallest equals 1, and the largest equals 12-14). 
VERON G. et al., Systematics and biogeography of the Hemigalinae civets

The systematics of the Hemigalinae had previously only been assessed using morphological data (Pocock 1933; Gregory \& Hellman 1939; Wozencraft 1989; Veron 1994, 1995) until Patou et al. (2008) proposed a molecular phylogeny of the Hemigalinae and Paradoxurinae. Patou et al. (2008) found that the banded civet and Owston's civet were sister species, with the otter civet as the sister taxon to these two (as also obtained later by Agnarsson et al. 2010). Unfortunately, Hose's civet and the Sulawesi palm civet Macrogalidia musschenbroekii (Schlegel, 1879) were missing from these molecular studies. Wilting \& Fickel (2012) provided data for these two species; they confirmed that Hose's civet is a member of the Hemigalinae, and found that the Sulawesi palm civet grouped with this subfamily (whereas it was previously classified within the Paradoxurinae; Wozencraft 2005). However, their phylogenetic trees showed very low branch support for some taxa, and the relationships between the species of Hemigalinae were not resolved.

Very few studies have explored intraspecific variation within the species of Hemigalinae. Veron et al. (2004) conducted a molecular study on Owston's civet and obtained two main groups: northern and central Vietnam; however, samples from China were missing. Based on morphological features, two species for the otter civet have been proposed, Cynogale lowei Pocock, 1933 and C. bennettii, but examination of the only specimen available for $C$. lowei, and doubt about its geographic origin, led Veron et al. (2006) to consider $C$. lowei as a synonym of $C$. bennettii. Four subspecies of the banded civet were proposed by Wozencraft (2005): Hemigalus derbyanus derbyanus (Gray, 1837) (Myanmar, Peninsular Malaysia, Sumatra); H. d. boei Muller, 1838 (Borneo); H. d. minor Miller, 1903 (South Pagai Island, Mentawai Islands); and $H$. d. sipora Chasen \& Kloss, 1927 (Sipora Island, Mentawai Islands). However, Pocock (1933) had previously proposed that $H$. d. derbyanus ranged from Myanmar to the Malay peninsula, Sumatra and Borneo, and that $H$. d. minor comprises both the South Pagai and Sipora Island populations. Corbet \& Hill (1992) did not find any morphological support for these subspecies, and there has been no recent taxonomic revision of $H$. derbyanus. On the basis of a short mitochondrial fragment, Wilting et al. (2012) suggested a split of ca 2.7 million years between $H$. d. derbyanus and H. d. minor; unfortunately, they did not provide details about their dataset and results, and their sequences are not available in GenBank.

Tectonic movements, geographical and ecological barriers, and climatic variations across Southeast Asia have played important roles in the speciation and population structure of forest-dependent species (Meijaard 2009; Esselstyn et al. 2010; Shekelle et al. 2010; Woodruff 2010; Veron et al. 2014, 2015b, $2015 \mathrm{c}$ ), and therefore, these might have affected the distribution and speciation of the Hemigalinae civets. The distinction between the Indochinese and Sundaic faunas might have arisen as a result of the rapid sea-level changes along the Thai-Malay peninsula during the last five million years, which caused local extirpations (Woodruff \& Turner 2009), or it has been maintained by the ecological differences between these two subregions (Meijaard 2009). Within the Sundaic region, climate-induced sea-level changes have altered the topography repeatedly, exposing and flooding land corridors between the mainland and different islands, and ecological factors played a role in restricting movements of species across this region. For instance, during the Last Glacial Maximum (LGM), the central part of the Sundaland might have been covered by open habitat (Bird et al. 2005; Meijaard 2003; de Bruyn et al. 2014; but see also Woodruff 2010), which could have limited the exchanges of forest-dependent species between Borneo and the rest of the Sundaic region (Veron et al. 2014; 2015c), and this could have affected the Hemigalinae civets.

The aims of this study were to further clarify the relationships of the species within the Hemigalinae, to study the intraspecific diversity and genetic structure within the banded and Owston's civets, and to explore the role of geographical barriers and environmental fluctuations in shaping the structure between and within species. We analysed three mitochondrial fragments, Cytochrome $b$, Control Region and NADH dehydrogenase subunit 2, and two nuclear genes, Beta-fibrinogen intron 7 and inter- 
photoreceptor retinoid binding protein (IPRB). Due to the elusive nature of the Hemigalinae civets and the difficulties of obtaining fresh samples, the use of museum samples was crucial for this study.

\section{Material and methods}

\section{Sampling, extraction, PCR and sequencing}

We collected fresh (hair or tissue) and museum samples (from skins and tissues taken from skulls) from 51 individuals of nine species of Hemigalinae and Paradoxurinae (Table 1, Fig. 1). Total genomic DNA was isolated following a cetyltrimethyl ammonium bromide (CTAB)-based protocol (Winnepenninckx et al. 1993). For museum samples, we added dithiothreitol (DTT 1M, ca $15 \mu 1$ per extract) during tissue lysis to break up disulfide bonds and we increased the lysis time (up to 72 hours).

We sequenced three mitochondrial fragments: Cytochrome $b$ gene (Cytb), the control region (CR; hypervariable region 1) and NADH dehydrogenase subunit 2 (ND2), using the primers from Veron et al. (2004, 2014, 2015a), Patou et al. (2008, 2009) and Wilting \& Fickel (2012). We sequenced the nuclear marker intron 7 of Beta-fibrinogen (FGB) using the primers of Yu \& Zhang (2005). IRBP sequences were from previous studies (see Table 1).

Polymerase chain reactions (PCRs) were performed as in Patou et al. (2010), with annealing temperatures of $50^{\circ} \mathrm{C}$ for Cytb and ND2, $61^{\circ} \mathrm{C}$ for CR, and $59^{\circ} \mathrm{C}$ for FGB. PCR products were visualized on a $1.5 \%$ agarose gel. PCR products were then purified and sequenced in both directions on an automated DNA sequencer by Genoscope and Eurofins. Sequences obtained from DNA extracted from museum samples were amplified and sequenced twice to ensure their quality and authenticity. Sequences were edited, assembled and aligned manually using Bioedit, version 7 (Hall 1999).

\section{Phylogenetic and haplotype network analyses}

Phylogenetic analyses were performed using neighbour-joining (NJ), maximum likelihood (ML) and maximum parsimony (MP) as implemented in MEGA6 (Tamura et al. 2013), and Bayesian inference (BI) using MrBayes 3.2 (Ronquist et al. 2012). We rooted the phylogenetic analyses with three Viverrinae (Genetta servalina Pucheran, 1855, Viverricula indica (Saint-Hilaire, 1803) and Viverra tangalunga Gray, 1832), one species of Felidae (Panthera leo (Linnaeus, 1758)) and two species of Herpestidae (Urva auropunctata (Hodgson, 1836) and U. javanica (Saint-Hilaire, 1818)). Individual loci were first analysed independently and then combined.

For ML, the best-fitting model was estimated prior to the analyses using MEGA6, following the Akaike information criterion (AIC). The selected model was then implemented in the ML analyses, using the Nearest-Neighbor-Interchange heuristic method and node robustness was assessed through 1000 bootstrap replicates. For the BI analysis combining the four genes (Cytb, ND2, FGB and IRBP), jModelTest v. 2.1.7 (Darriba et al. 2012) was used to evaluate the models of nucleotide substitution for each of the ten partitions (FGB and the three codon-positions for Cytb, ND2 and IRBP), following the Akaike information criterion. Bayesian analyses were then conducted using the selected GTR $+\mathrm{I}+\mathrm{G}$ model for Cytb-1 and Cytb-3, GTR + G model for Cytb-2 and ND2-3, GTR model for FGB, HKY + I + G model for ND2-1, HKY + G model for ND2-2, HKY model for IRBP-1 and IRBP-3, and K80 model for IRBP-2. The posterior probabilities (PP) were calculated using four independent Markov chains run for 10000000 Metropolis-coupled MCMC generations, with trees sampled every 1000 generations and a burn-in of $25 \%$.

Trees were visualized and edited using FigTree v. 1.4.0 (Rambaut 2012). We compared resulting topologies and their node support; nodes were considered as supported when posterior probabilities were $\geq 0.95$ and bootstrap values were $\geq 70 \%$ (see Alfaro et al. 2003). 


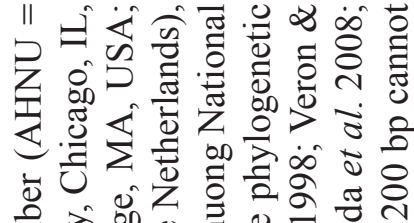

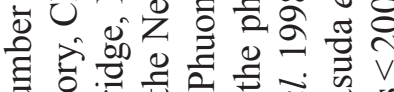

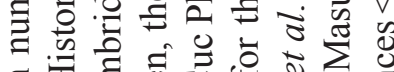

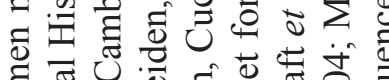

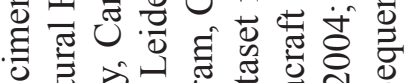

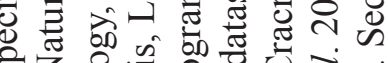
की 药

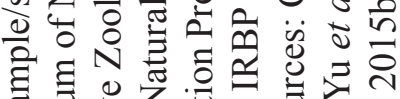

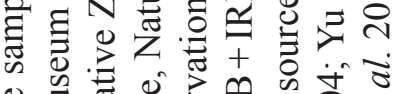

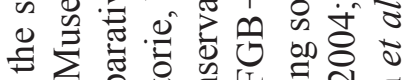

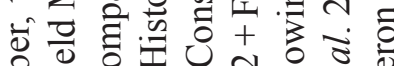
है

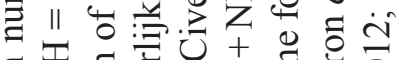

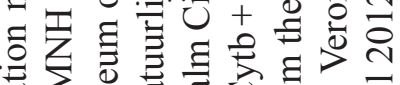

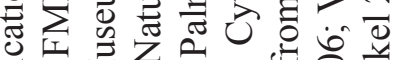

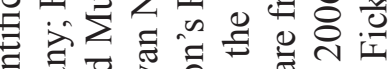

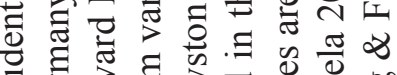

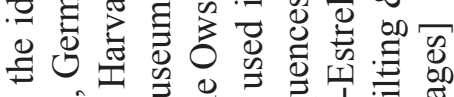
ㅍㅟㅔ

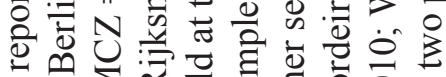

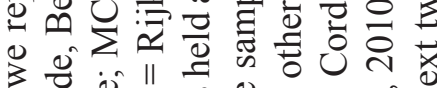
उ छ

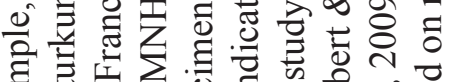

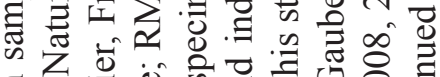

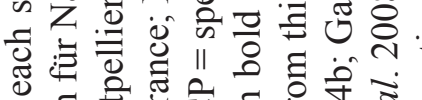

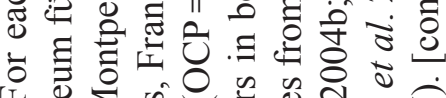
I

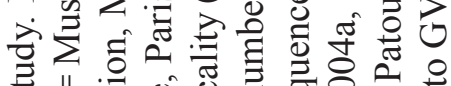

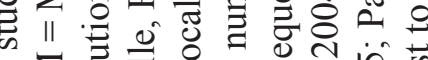

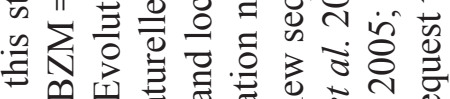

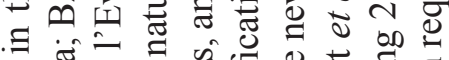

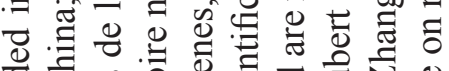

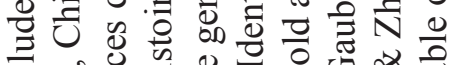
过 : 月

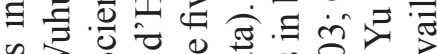
๘

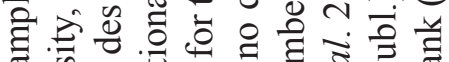

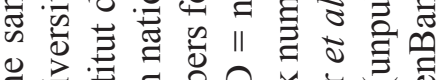

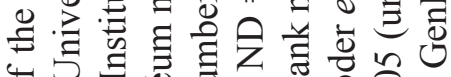

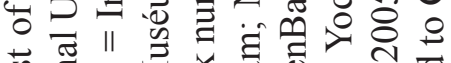

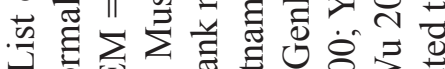

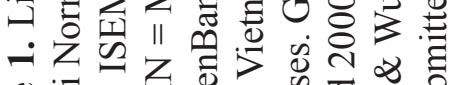

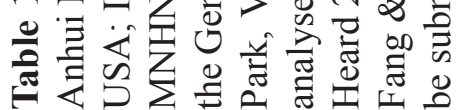

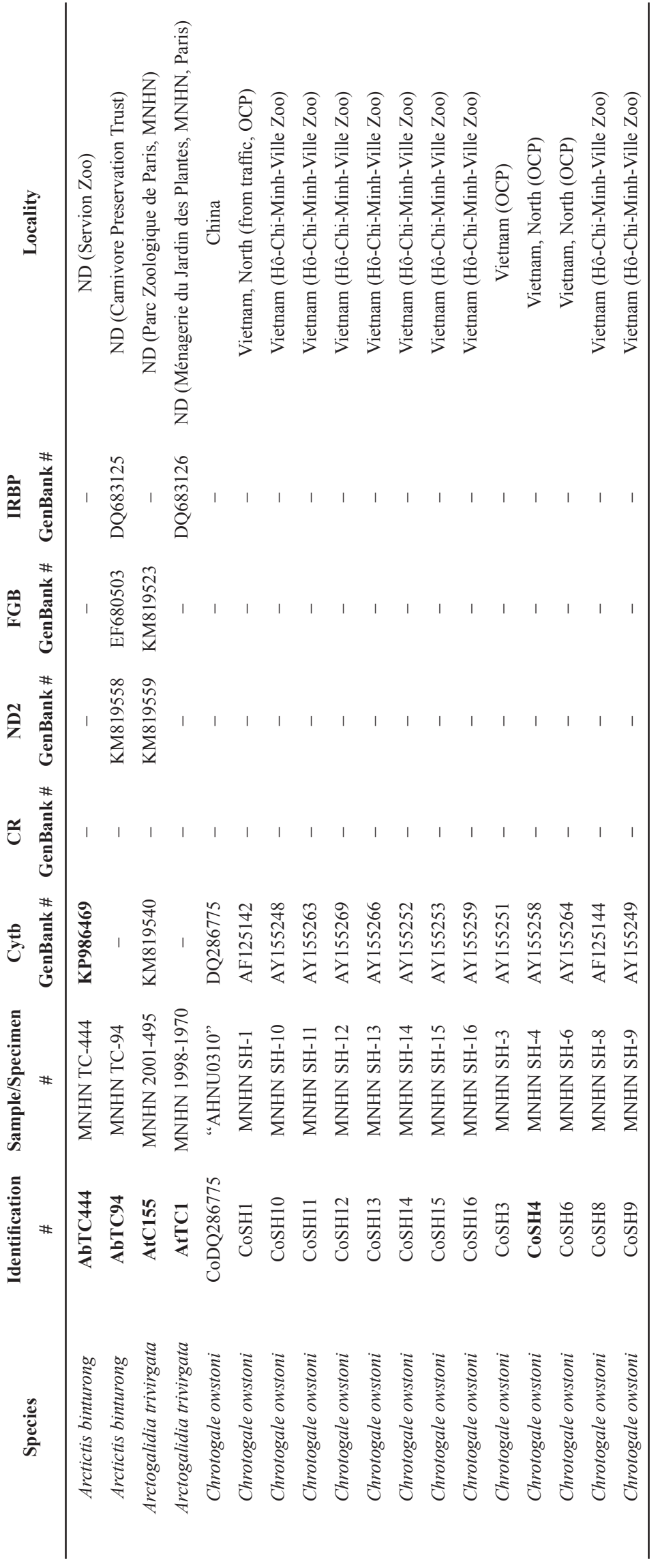




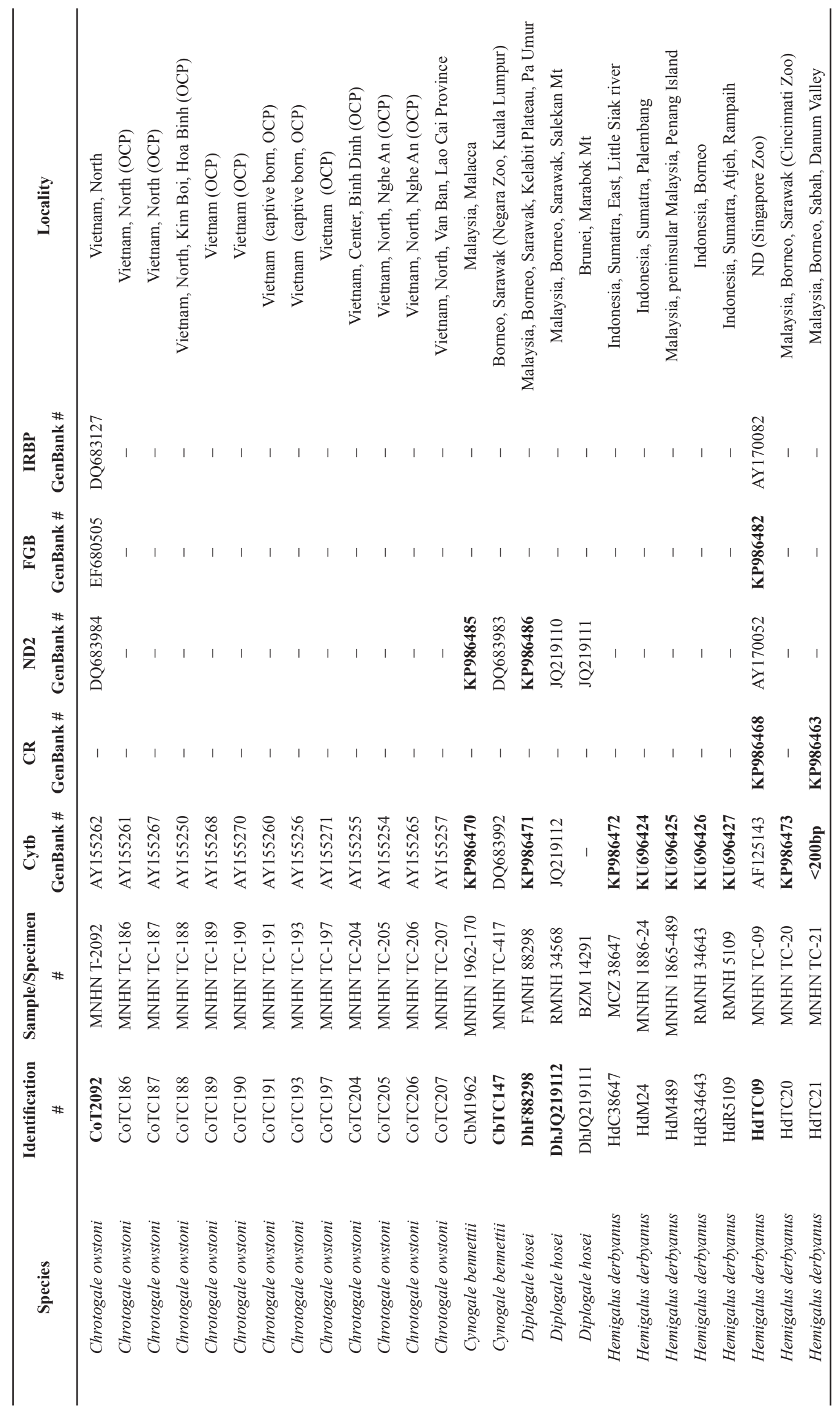




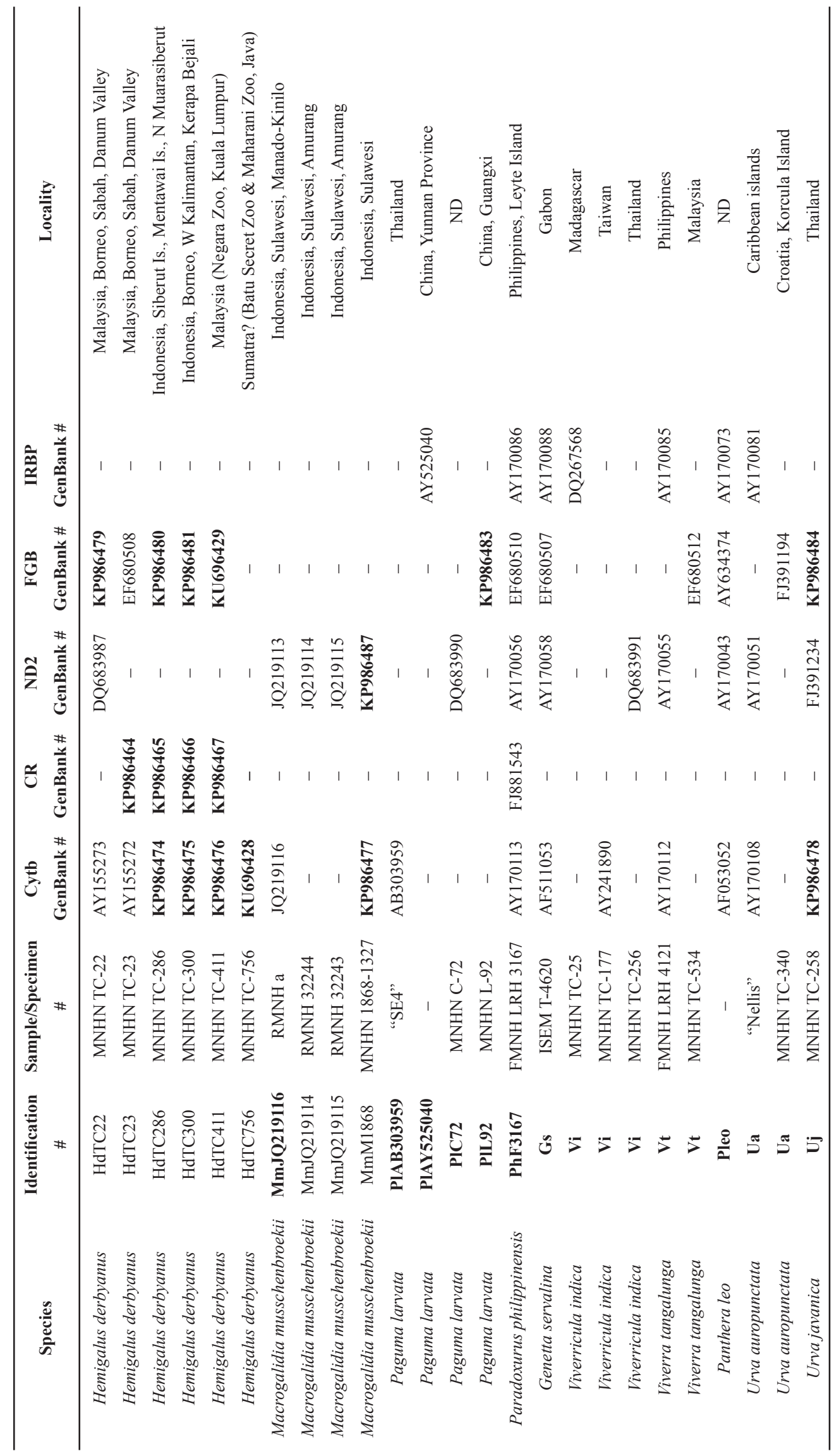


We used DnaSP v. 5.10 (Librado \& Rosas 2009) to define haplotypes and to compute genetic diversity (haplotype and nucleotide diversity), and NETWORK v. 4.6 (www.fluxus-engineering.com) to construct haplotype median-joining networks (Bandelt et al. 1999).

We computed genetic distances (within and between groups) and genetic diversity (haplotype and nucleotide diversity) using MEGA6 and DnaSP v. 5.10.

\section{Results}

All new sequences were deposited in GenBank (accession numbers: KP986463 to KP986487 and KU696424 to KU696429; Table 1). Due to the degraded nature of DNA retrieved from samples taken from museum specimens and poorly preserved tissue, only partial sequences could be obtained from some samples and nuclear sequences were not retrieved from museum specimens. For the Diplogale hosei Cytb sequence from GenBank (JQ219112; Wilting \& Fickel 2012), we replaced the nucleotides in position 327 to 344 by ' $\mathrm{N}$ ', as we strongly suspected that these nucleotides were those of the primer sequence (their primer CytBViv0323f), based on a comparison within the alignment.

The Cytb and ND2 fragments that we obtained from a D. hosei specimen (FMNH 88298) differed by $0.5 \%$ and $1.5 \%$ to the two individuals sequenced by Wilting \& Fickel (2012). The Cytb sequence of a specimen of Cynogale bennettii (MNHN 1962-170) did not differ from the sequence of the individual sequenced by Patou et al. (2008), while the ND2 sequence differed by $0.7 \%$. The Cytb fragment of a Macrogalidia musschenbroekii specimen (MNHN 1868-1327) did not differ from the three sequences obtained by Wilting \& Fickel (2012), while its ND2 sequence differed by $0.0-0.6 \%$. Any differences we found may reflect sequencing errors, which can happen with ancient DNA, or were due to individual variations (and these differences were not higher than the intraspecific variations observed within other species of Viverridae).

All gene fragments were analysed both individually and combined, with the different phylogenetic methods. The phylogenetic analyses of the dataset combining Cytb, ND2, FGB, and IRBP (length of the alignment, number of variable positions and number of parsimony-informative sites: 3342/1226/801, $n=15$, including 6 outgroups) confirmed the monophyly of the Hemigalinae and Paradoxurinae (Fig. 2). Within the Hemigalinae, Hemigalus and Chrotogale are sister species (with a Bayesian posterior probability (bpp) of 0.91; ML boostrap $=96 \%$ ), and Diplogale is sister to these two species in the BI tree (bpp=1; Fig. 2), as well as in the MP tree (MP boostrap $>50 \%$ ), while in the ML tree, the position of Diplogale within this subfamily was unresolved (Fig. 2). Macrogalidia clusters within the Hemigalinae in all analyses (bpp =1; ML boostrap $=99 \%$; Fig. 2); it is sister to Cynogale in the BI tree (bpp=0.90), but its position (and that of Cynogale) within this subfamily were unresolved in the ML and MP trees.

For the complete Cytb (1140 bp, $n=46)$, the distances between the two subfamilies (as previously defined) for Hemigalinae (without Macrogalidia) and Paradoxurinae (including Macrogalidia) ranged from $12.5 \%$ to $17.6 \%$. The average Cytb distance between the two clades obtained in our study, Hemigalinae including Macrogalidia and Paradoxurinae without Macrogalidia, was $15.9 \%$, and the mean within group distances were 7.2\% and 12.3\%, respectively. The distances between Macrogalidia and the species of Hemigalinae ranged from $12.0 \%$ to $14.9 \%$, and to the species of Paradoxurinae from $14.4 \%$ to $15.9 \%$. The mean distances between the remaining four species of the Hemigalinae clade ranged from $11.9 \%$ to $16.7 \%$; the most distant species to the other three was Cynogale, and the smallest mean distance was between Hemigalus and Chrotogale.

We analysed a fragment of Cytb (895 bp, positions 123-1015 in complete Cytb alignment) for $H$. derbyanus and C. owstoni in order to search for geographical structure within these two species (895/241/142; n=39; model GTR + I + G; Fig. 3). H. derbyanus was structured into two main clades: 
one containing an individual from Siberut Island (Mentawai Islands) and a second clade that comprised all other individuals (Fig. 3). The overall mean distance within $H$. derbyanus was $1.6 \%$; the mean distances of the Siberut Island individual to those from Sumatra and Borneo were $4.7 \%$ and $5.5 \%$, respectively, whereas it ranged from $1.0 \%$ to $1.3 \%$ between Sumatra, Borneo and Peninsular Malaysia. C. owstoni formed one group from northern Vietnam (although its monophyly was poorly supported or not retrieved in some analyses), that is sister group to another from central Vietnam, whereas the individual from China was distant to these two (Fig. 3). The overall mean distance within C. owstoni was $1.1 \%$; the mean distance between the two Vietnam groups was $1.4 \%$, while the Chinese individual was separated from the latter groups by a mean distance of $2.1 \%$ to $3.4 \%$.

A fragment of CR was obtained for a few individuals of $H$. derbyanus $(592 / 18 / 0, n=6)$ and provided a similar phylogenetic structure (not shown) as Cytb, with the same two main clades; the mean distance between the Siberut Island individual and the others was 4.7\%. We obtained four CR haplotypes (195 bp excluding missing data; haplotype diversity, Hd: 0.8; nucleotide diversity, Pi: 0.01880; average number of nucleotide differences, $\mathrm{k}: 3.667$ ), with the Siberut Island individual separated by eight to ten mutations to any other haplotype.

We also used a Cytb fragment (834 bp, positions 129-962 in Cytb alignment) to compute haplotype networks for $H$. derbyanus and C. owstoni. For H. derbyanus, we obtained eight haplotypes (Hd: 0.972; Pi: 0.01952 ; k: 16.278; n=9; Fig. 4), with the Siberut Island haplotype (H6) separated by 39 mutations from the other individuals. One Sumatra individual (H1) was separated from a haplogroup of Borneo and zoo individuals. For C. owstoni, we obtained 19 haplotypes (Hd: 0.9692; Pi: 0.00886; k: 7.345;

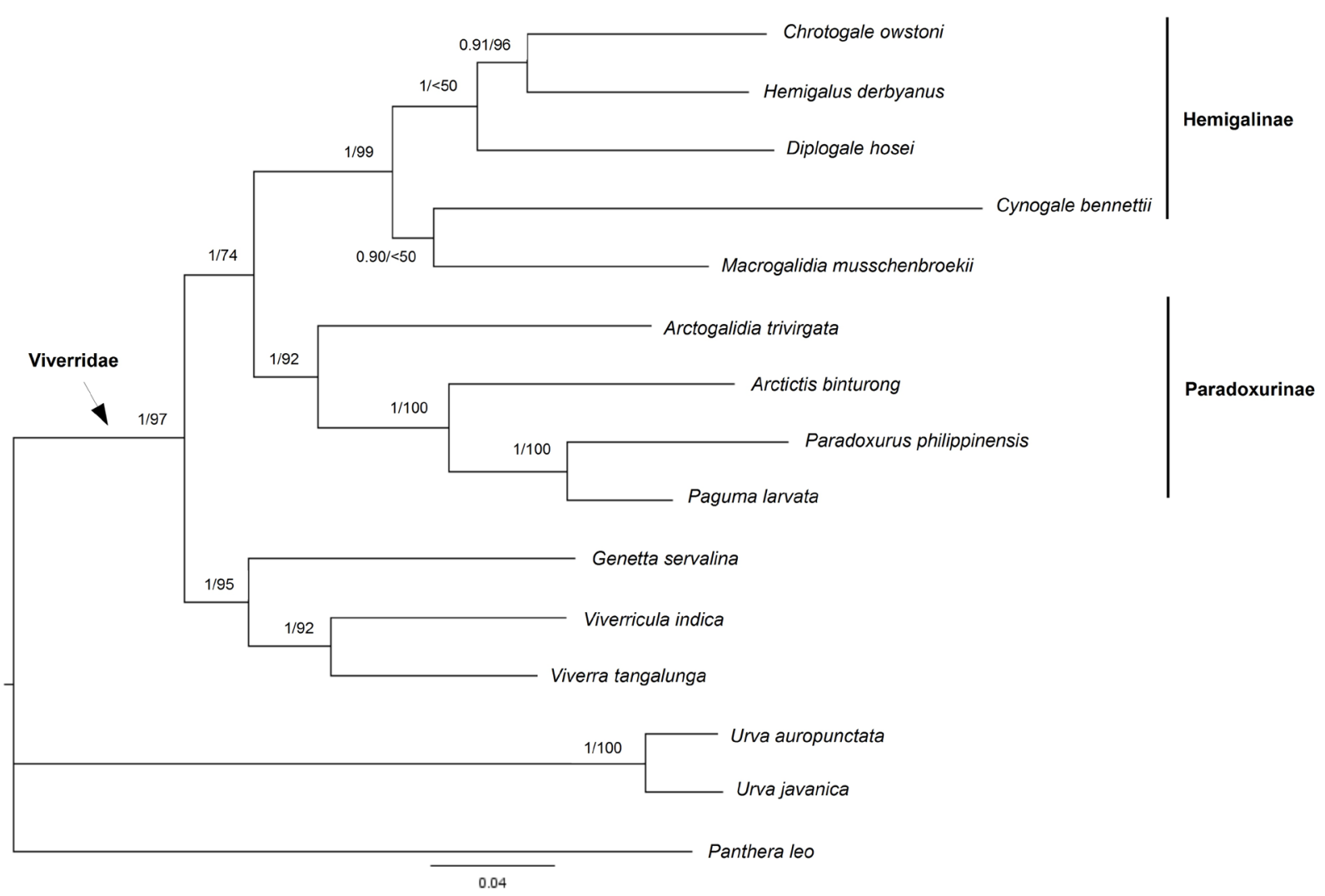

Fig. 2. Bayesian tree reconstructed from a combined dataset of Cytb + ND2 + FGB + IRBP (3342 bp). The values on the branches are bayesian posterior probabilities for the partitioned analysis (see text for models) and bootstrap proportions obtained from ML analysis (model: GTR $+\mathrm{I}+\mathrm{G}$ ). 


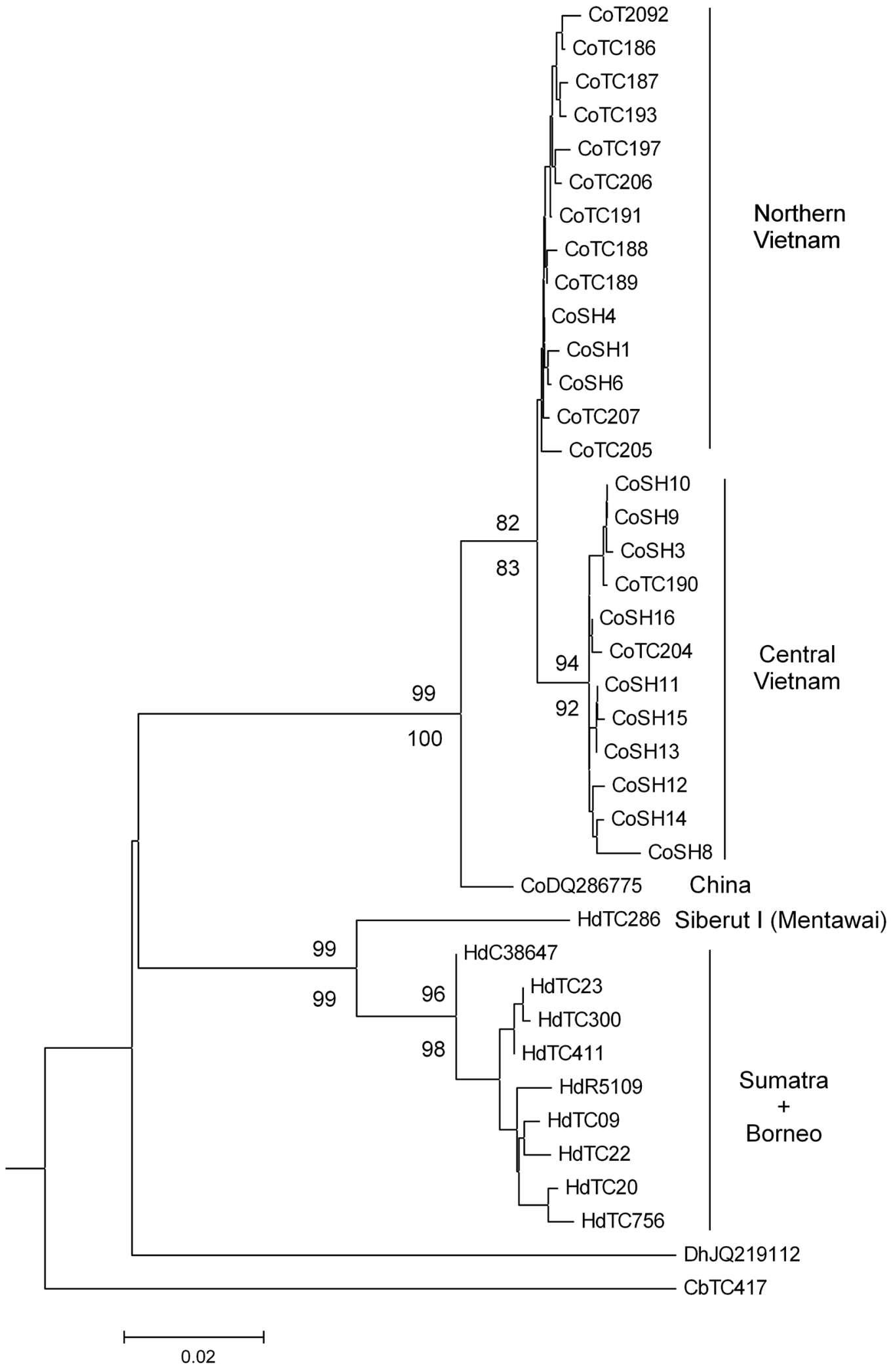

Fig. 3. Phylogenetic tree obtained with NJ for a fragment of Cytb ( $893 \mathrm{bp}$ ). The values over the branches are the bootstrap proportions for NJ, and below the branches are those for ML. Co $=$ Chrotogale owstoni Thomas, 1912; Hd = Hemigalus derbyanus (Gray, 1837); $\mathrm{Dh}=$ Diplogale hosei (Thomas, 1892); Cb = Cynogale bennettii Gray, 1837. 
$\mathrm{n}=26$; Fig. 5), forming two groups for northern and southern Vietnam, separated by eight mutations (the Chinese individual could not be used in this analysis due to missing data).

We also computed haplotypes using smaller Cytb fragments in order to include additional individuals of various origins. For $H$. derbyanus, using a 253 bp fragment in the 3 ' region (positions 768-1020 in the Cytb alignment), we obtained six haplotypes (Hd: 0.8030; Pi: 0.01509; k: 3.818; $\mathrm{n}=12$; Figure 4), organized in a star-like structure, with a central haplotype (H5) from Borneo (and also zoo individuals); the Siberut Island (Mentawai) individual (H6) was separated by 13 mutations from the two Sumatra haplotypes (H2 and H4), which were separated from the Borneo haplotype (H5) by two mutations; the individual from Peninsula Malaysia (H3) was separated by one mutation from the Borneo haplotype; another haplotype (H1) comprising individuals from Borneo and Sumatra was three mutations distant from the Borneo haplotype (H5). For C. owstoni, using another $253 \mathrm{bp}$ fragment in the 5' region (positions 123-375 in Cytb alignment), we obtained six haplotypes (Hd: 0.7000; Pi: 0.00901; k: 2.280; n = 25; Fig. 5); northern Vietnam individuals formed a haplogroup of three haplotypes (H2, H5, H6), while central Vietnam individuals formed a haplogroup of two haplotypes (H3, H4); the Chinese individual (H1) was separated from these groups by a minimum of five and eight mutations, respectively; the northern and central Vietnam groups were separated by a minimum of three mutations.

We also computed haplotypes for the $H$. derbyanus FGB dataset ( $321 \mathrm{bp}$ ), and we obtained three haplotypes (Hd: 0.6000; Pi: 0.00415; k: 1.333; n=6); the Siberut Island (Mentawai Islands) individual was separated by three and four mutations from the other two haplotypes (not shown).

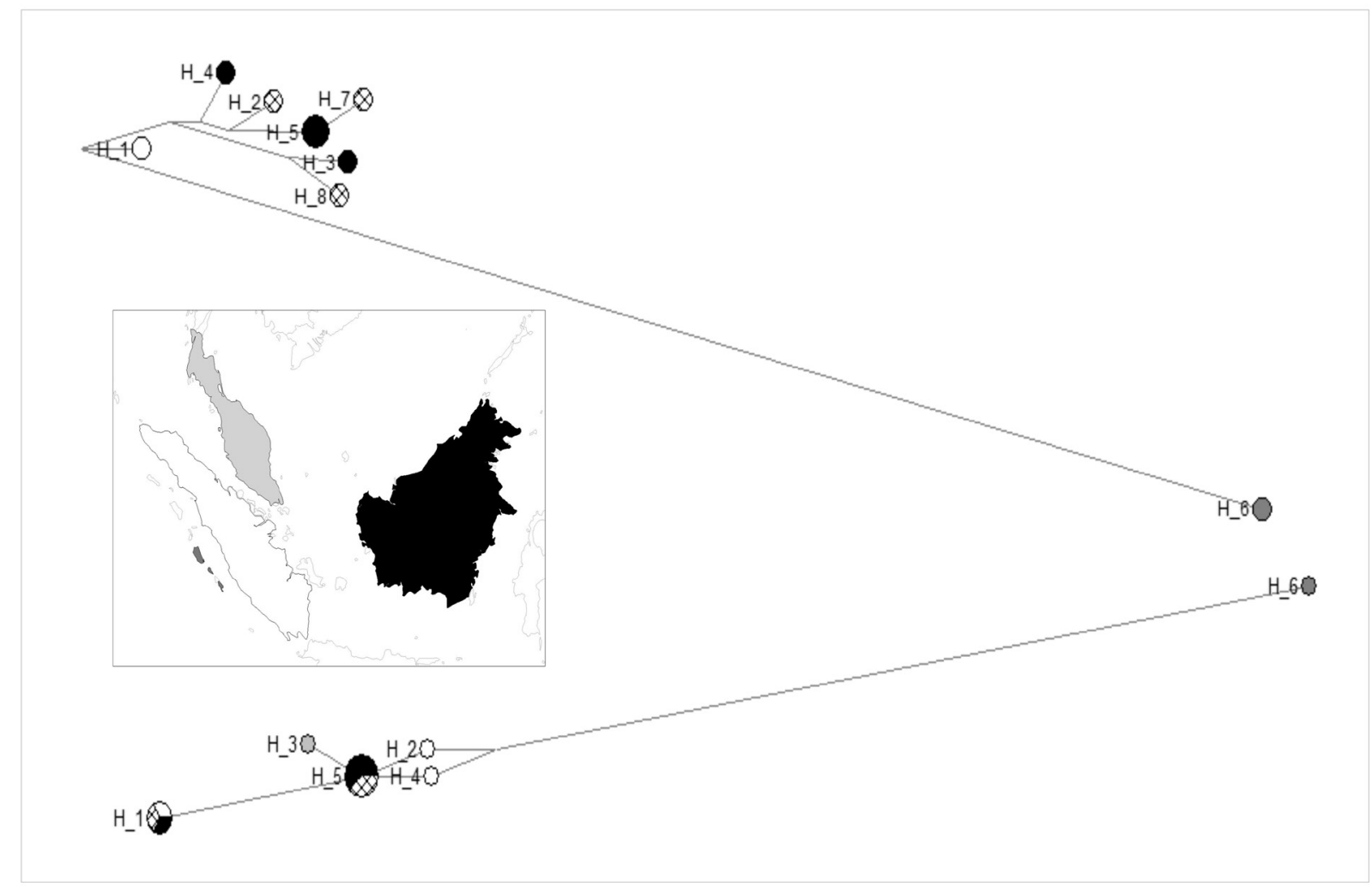

Fig. 4. Median-joining haplotype network for Hemigalus derbyanus (Gray, 1837) Cytb haplotypes (top: $837 \mathrm{bp}$, bottom: 253bp). The size of each circle is proportional to the haplotype frequency. The colours of the haplotypes correspond to those on the map: black = Borneo; dark grey $=$ Siberut Island (Mentawai Islands); light grey $=$ Penang Island (Peninsular Malaysia); white $=$ Sumatra; hatched $=$ Zoo samples (on top network: Singapore Zoo (H2), Negara Zoo, Kuala Lumpur (H7) and Batu Secret Zoo \& Maharani Zoo, Java (H8)). 
Our results suggest that the $H$. derbyanus individuals from the Singapore Zoo (HdTC09), the Negara Zoo in Kuala Lumpur (TC-411), and the Batu Secret Zoo \& Maharani Zoo in Java (TC-756) all come from Borneo, despite the fact that the latter individual was supposed to come from Sumatra. The individual from the Cincinnati Zoo (TC-20) was supposed to come from Borneo and our results agree with this.

\section{Discussion}

While Wilting \& Fickel (2012) did not obtain a resolution for the banded, Hose and Owston's civets relationships, our study found that the banded and Owston's civets are sister species, and also suggested that Hose's civet might be the sister species to these two.

Similar to Wilting \& Fickel (2012), the Sulawesi palm civet was found within the Hemigalinae. It either clustered with the otter civet (although this was weakly supported) or its position was unresolved. These two species had missing data (nuclear genes) and long branches (in particular the otter civet), which could have affected their phylogenetic position; long branch attraction is a commonly recognized artefact in phylogenetic reconstruction that can produce misleading (but sometimes strongly supported) relationships (Felsentein 1978; Simmons 2012). Also, the use of only mitochondrial data can lead to misleading relationships at ordinal and also lower taxonomic levels (e.g., for carnivores, Sato et al. 2003). For example, prior to the addition of nuclear data, the small-toothed palm civet Arctogalidia trivirgata was not retrieved within the Paradoxurinae (Patou et al. 2008). Morphological features support the inclusion of the Sulawesi palm civet in the Paradoxurinae (Gaubert et al. 2005), which either invalidates

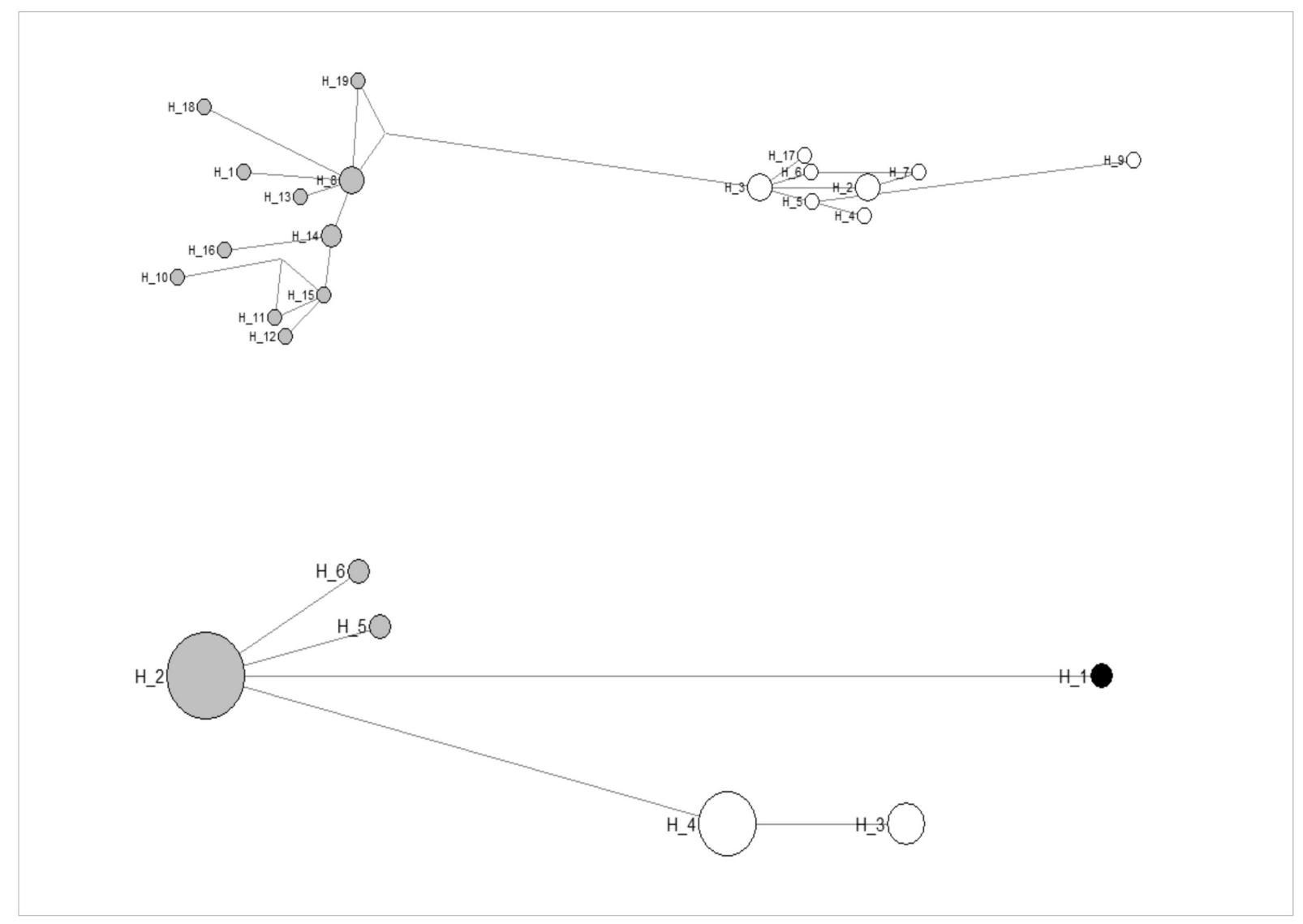

Fig. 5. Median-joining haplotype network for Chrotogale owstoni Thomas, 1912 Cytb haplotypes (top: $837 \mathrm{bp}$, bottom: $235 \mathrm{bp}$ ). The size of each circle is proportional to the haplotype frequency. White $=$ central Vietnam clade; grey $=$ northern Vietnam clade, black $=$ China . 
VERON G. et al., Systematics and biogeography of the Hemigalinae civets

the molecular results, or indicates homoplasy in the morphological features. Further genetic studies, with additional samples and data (nuclear genes) are needed to clarify further the phylogenetic position of the Sulawesi palm civet. We advocate that further studies be conducted before moving Macrogalidia to the Hemigalinae. The Sulawesi palm civet is a threatened species endemic to Sulawesi (Jennings \& Veron 2009; IUCN 2015), and is the only native carnivore found east of Wallace's Line (Veron 2001). Hall (2001) found evidence of a land bridge west of Sulawesi ca 20 million years ago (Mya), and suggested faunal exchanges between Sulawesi and the rest of Southeast Asia occurred ca 10 Mya. More recently, it has been suggested that colonisations of Sulawesi started during the early Miocene, and that speciation events happened as early as 20 Mya (Stelbrink et al. 2012). Patou et al. (2008) proposed that the Hemigalinae diverged 15.4-8.4 Mya, which corresponds to the dates of origin of several Sulawesi taxa (Stelbrink et al. 2012). These findings suggest that the Sulawesi palm civet diverged from the other species more than 10 Mya, which is supported by its high Cytb divergence (12.0-14.9\%) from its relatives. This ancient speciation explains why the analysis of only mitochondrial sequences has not fully resolved its phylogenetic relationships.

The northern distribution limit of the banded civet is close to the Isthmus of Kra, along the Thai-Malay Peninsula (Jennings et al. 2013), which is a transitional region between the Indochinese and Sundaic faunas (Woodruff \& Turner 2009; Meijaard 2009). The range of Owston's civet is restricted to southern China, Laos, and Vietnam (Jennings \&Veron 2009). Eustatic and climatic events in this region may have caused the speciation of these two civet species (with subsequent range restrictions due to habitat changes that occurred during the Plio-Pleistocene and more recently to human-induced modifications). Hose's civet is found only on Borneo, where it is sympatric with the banded civet (although there is a tendency for these two species to separate spatially along an elevation gradient; Jennings et al. 2013). However, we do not know if Hose's civet might have had a wider distribution in the past and was then restricted to forest refugia in the mountains of Borneo during Plio-Pleistocene climatic variations, or if it speciated on Borneo from an ancestor of Hemigalus + Chrotogale. The otter civet is a specialised viverrid that is adapted to aquatic life (with webbed feet, and nostrils and ears that can be closed by flaps) that ranges across the Sundaic region (Veron et al. 2006), and it could have diverged first within the subfamily.

We found a strong geographical genetic structure in the banded and Owston's civets. Within the banded civet, the individual from Siberut Island (Mentawai Islands) was very distant from the populations from both Sumatra and Borneo (for both Cytb and FGB), and according to our haplotype networks it is closer to Sumatra individuals. In contrast, the Mentawai population of the common palm civet (Paradoxurus sp.) was found to be closer to those from Borneo and the Philippines (Paradoxurus philippinensis) than to the nearby Sumatran populations (Paradoxurus musangus) (Patou et al. 2010; Veron et al. 2015c). Although the four Mentawai Islands (Siberut, Sipora, North and South Pagai) are close to Sumatra, they are separated by a deep sea channel, the Mentawai Strait, which has isolated populations and explains the high level of species endemism on these islands (Wilting et al. 2012). Their strong divergence from Sumatran populations might also be explained by local extinctions during the Pleistocene (Patou et al. 2010; Wilting et al. 2012) and the Mentawai Islands might have served as a forest refuge during glaciations. The divergence time of Mentawai taxa has been estimated from 1.1 to 3.5 Mya in mammals (Patou et al. 2010; Wilting et al. 2012). The Mentawai Islands have been separated from Sumatra at least since the Mid-Pleistocene and might have remained separated despite the sea level fluctuations of the Late Pleistocene (Voris 2000; Wilting et al. 2012). The Cytb distance of the Siberut Island individual to other banded civet populations ranged from 4.7 to $5.5 \%$, which is close to the divergence found between other small carnivore species (Veron et al. 2007, 2015a, 2015c); our nuclear data also confirmed this strong divergence. Two subspecies have been described from the Mentawai Islands: Hemigalus derbyanus minor Miller, 1903 (South Pagai Island) and H. d. sipora Chasen \& Kloss, 1927 (Sipora Island). Very little is known about the population from Siberut Island, which has not been attributed to 
any subspecies (Jennings et al. 2013). The four Mentawai Islands were likely connected during periods of lower sea levels (Sathiamurthy \& Voris 2006), and there does not seem to be any endemism on each island, as several species occur on all or several of the four islands (Sargis et al. 2014). It is therefore likely that banded civets from the islands of Siberut, Sipora and South Pagai belong to the same taxon, which would be Hemigalus derbyanus minor.

Banded civet individuals from Sumatra were not strongly divergent from those from Borneo, whereas a strong divergence between Sumatran and Borneo populations has been found in other forest species (Veron et al. 2015a). Borneo has been isolated from Sumatra for ca 20000 years, at the end of the Last Glacial Maximum, and even when land connections existed between Borneo and the rest of the Sundaic region, open habitat might have restricted the movements of some forest animals (Meijaard 2003; Bird et al. 2005; Cannon et al. 2009). Our results suggest that there have been independent connections between Borneo and Sumatran populations, and between Borneo and Peninsular Malaysian populations (in this study represented by an individual from Penang Island, which is very close and connected to the NW coast of Peninsular Malaysia). Although Peninsular Malaysia and Sumatra have been connected frequently during glacial periods, the banded civet individuals from these two areas did not form a monophyletic group in our analyses, whereas a close relationship and low differentiation of populations from Sumatra and Peninsular Malaysia have been found in many other mammals, such as rodents, macaques, palm civets and mongooses (Gorog et al. 2004; Ziegler et al. 2007; Patou et al. 2010; Veron et al. 2015a). Possible explanations for these findings would be independent dispersals during periods of lower sea levels (e.g., Last Glacial Maximum), or that banded civets were transported from one area to another, as has been suggested for some other civet species (Veron et al. 2014, 2015c), although there is no evidence that this has ever occurred for the banded civet. With regards to the structure obtained and the low divergences observed, we would suggest that the populations from Sumatra, Peninsular Malaysia and Borneo are placed in the same subspecies Hemigalus derbyanus derbyanus (Gray, 1837).

Within Owston's civet, we obtained two main groups in Vietnam, which confirms the finding of Veron et al. (2004), and we found a third group from China, quite distant from the northern Vietnam group. This might have resulted from either geographic barriers or Pleistocene climatic fluctuations (as suggested for bats, see Tu et al. 2017) that shaped the population structure of this species. However, only one sequence was available for China (and it came from GenBank so we cannot confirm its validity), and thus, additional data would be needed to confirm this finding. These three groups could have been maintained due to limited exchanges between isolated populations as a result of habitat destruction (see IUCN 2015). To assess whether these populations should be considered subspecies would require further investigations, as the origin of several individuals was uncertain and samples from Laos were missing in our dataset. This is a very poorly known, endangered civet species that is severely threatened by forest loss, hunting and the wildlife trade (Willcox et al. 2011; Coudrat et al. 2014).

Further studies are needed on the intraspecific diversity and genetic structure of the Hemigalinae civets, and for the designation of conservation units, in particular, for island endemic species and subspecies. Unfortunately, due to their elusive nature, these civet species have rarely been studied in the wild and are very rarely trapped, so obtaining fresh samples is extremely difficult. Finally, ecological studies are urgently needed in order to better understand and assess the conservation status of these threatened species.

\section{Acknowledgements}

We thank the following people and institutions for their contribution to this study: F. Catzeflis (Institut des Sciences de L'Evolution, Université de Montpellier), C.P. Colon (Fordham University), R. Debruyne (UMS CNRS 2700, MNHN, Paris), A. Erman \& E. Meijaard (People \& Nature Consulting International), M.F. Gorra (Carnivore Preservation Trust), L. Grassman (Texas A\&M University 
VERON G. et al., Systematics and biogeography of the Hemigalinae civets

- Kingsville), L.L. Lee (Taiwan University), B. Long (World Wildlife Fund), P. Martelli (Singapore Zoological Gardens), J. Patton (Museum of Vertebrate Zoology, Berkeley, CA), M.L. Patou (Biotope), S. Roberton (FFI, Owston's Palm Civet Conservation Program), T.L. Roth (Cincinnati Zoo), S. Vellayan (Zoo Negara, Kuala Lumpur), Siew Te Wong (Borneo Sun Bear Conservation Center), Servion Zoo, D. Boussarie, and S. Heard. We thank the following curators and museums for access to specimens and samples: N. Duncan, E. Westwig, E. Hoeger (American Museum of Natural History, New York), L.R. Heaney, J.D. Phelps, the late W.T. Stanley (Field Museum of Natural History, Chicago), M. Omura, B. Zimkus, J. Chupasko (Harvard Museum of Comparative Zoology, Cambridge, MA), S. van der Mije, P. Kamminga (Naturalis, Leiden, the Netherlands) and K.K.P. Lim (Raffles Museum of Biodiversity Research, Singapore). Thanks are due to the Forest Protection Department of Vietnam's Ministry of Agriculture \& Rural Development for their permission to export samples. We thank the EPU and PERHILITAN for permission to conduct research in Malaysia, and S. Ellagupillay (PERHILITAN) and Z. Akbar (University Kebangsaan Malaysia) for their support; funding for the Malaysian Carnivore Project is acknowledged at www.smallcarnivores.org. Molecular work was undertaken at the 'Service de Systématique Moléculaire' (UMS CNRS 2700, MNHN, Paris), and we thank the staff of the lab for their help. The sequencing was supported by the network "Bibliothèque du Vivant" funded by CNRS, MNHN, INRA and CEA (Genoscope, www.genoscope.fr). G.V. received financial support from MNHN, CNRS, and from the "Action Transversale du Muséum, Biodiversité actuelle et fossile" (MNHN, French Ministry of Research). We thank the Associate Editor and anonymous reviewers for their useful suggestions on an earlier version of this paper.

\section{References}

Agnarsson I., Kuntner M. \& May-Collado L.J. 2010. Dogs, cats, and kin: A molecular specieslevel phylogeny of Carnivora. Molecular Phylogenetics and Evolution 54: 726-745. http://dx.doi. org/10.1016/j.ympev.2009.10.033

Alfaro M.E., Zoller S. \& Lutzoni F. 2003. Bayes or bootstrap? A simulation study comparing the performance of Bayesian Markov chain Monte Carlo sampling and bootstrapping in assessing phylogenetic confidence. Molecular Biology and Evolution 20: 255-266. http://dx.doi.org/10.1093/ molbev/msg028

Bandelt H.J, Forster P. \& Röhl A. 1999. Median-joining networks for inferring intraspecific phylogenies. Molecular Biology and Evolution 16: 37-48.

Bird M.I., Taylor D. \& Hunt C. 2005. Palaeoenvironments of insular Southeast Asia during the Last Glacial Period: a savanna corridor in Sundaland? Quaternary Science Reviews 24: 2228-2242. http:// dx.doi.org/10.1016/j.quascirev.2005.04.004

Cannon C.H., Morley R.J. \& Bush A.B.G. 2009. The current refugial rainforests of Sundaland are unrepresentative of their biogeographic past and highly vulnerable to disturbance. Proceedings of the National Academy 106: 11188-11193. http://dx.doi.org/10.1073/pnas.0809865106

Corbet G. \& Hill J. 1992. The Mammals of the Indomalayan Region. Oxford University Press, Oxford.

Corlett R.T. 2009. The Ecology of Tropical East Asia. Oxford University Press, Oxford.

Coudrat C.N.Z., Nanthavong C., Sayavong S., Johnson A., Johnston J.B. \& Robichaud W.G. 2014. Conservation importance of Nakai-Nam Theun National Protected Area, Laos, for small carnivores based on camera trap data. Raffles Bulletin of Zoology 62: 31-49.

Cracraft J., Feinstein J., Vaughn J. \& Helm-Bychowski K. 1998. Sorting out tigers (Panthera tigris): mitochondrial sequences, nuclear inserts, systematics, and conservation genetics. Animal Conservation 1: 63-74. http://dx.doi.org/10.1111/j.1469-1795.1998.tb00021.x 
Darriba D., Taboada G.L., Doallo R., Posada D. 2012. jModelTest 2: more models, new heuristics and parallel computing. Nature Methods 9: 772. http://dx.doi.org/10.1038/nmeth.2109

De Bruyn M., Stelbrink B., Morley R.J., Hall R., Carvalho G.R., Cannon C.H., Van Den Bergh G., Meijaard E., Metcalfe I., Boitani L., Maiorano L., Shoup R. \& Von Rintelen T. 2014. Borneo and Indochina are major evolutionary hotspots for Southeast Asian biodiversity. Systematic Biology 63: 879-901. http://dx.doi.org/10.1093/sysbio/syu047

Esselstyn J.A., Oliveros C.H., Moyle R.G., Peterson A.T., McGuire J.A. \& Brown R.M. 2010. Integrating phylogenetic and taxonomic evidence illuminates complex biogeographic patterns along Huxley's modification of Wallace's Line. Journal of Biogeography 37: 2054-2066. http://dx.doi.org/10.1111/ j.1365-2699.2010.02378.x

Felsenstein J. 1978. Cases in which parsimony or compatibility methods can be positively misleading. Systematic Zoology 27: 401-410. http://dx.doi.org/10.2307/2412923

Gaubert P. \& Cordeiro-Estrela P. 2006. Phylogenetic systematics and tempo of evolution of the Viverrinae (Mammalia, Carnivora, Viverridae) within feliformians: Implications for faunal exchanges between Asia and Africa. Molecular Phylogenetics and Evolution 41: 266-278. http://dx.doi.org/10.1016/j. ympev.2006.05.034

Gaubert P., Fernandes C.A., Bruford M.W. \& Veron G. 2004a. Genets (Carnivora, Viverridae) in Africa: an evolutionary synthesis based on cytochrome $b$ sequences and morphological characters. Biological Journal of the Linnean Society 81: 589-610. http://dx.doi.org/10.1111/j.1095-8312.2004.00309.x

Gaubert P., Tranier M., Delmas A.S., Colyn M. \& Veron G. 2004b. First molecular evidence for reassessing phylogenetic affinities between genets (Genetta) and the enigmatic genet-like taxa Osbornictis, Poiana and Prionodon (Carnivora, Viverridae). Zoologica Scripta 33: 117-129. http://dx.doi.org/10.1111/ j.1463-6409.2004.00140.x

Gaubert P., Wozencraft W.C., Cordeiro-Estrela P. \& Veron G. 2005. Mosaic of convergences, noise and misleading morphological phylogenies: what's in a viverrid-like carnivoran? Systematic Biology 54: 865-894. http://dx.doi.org/10.1080/10635150500232769

Gregory W.K. \& Hellman H. 1939. On the evolution and major classification of the civets (Viverridae) and allied fossil and recent Carnivora; a phylogenetic study of the skull and dentition. Proceedings of the American Philosophical Society 81: 309-392.

Haig S.M. 1998. Molecular contributions to conservation. Ecology 79: 413-425.

Hall R. 2001. Cenozoic reconstructions of SE Asia and the SW Pacific: changing patterns of land and sea. In: Metcalfe I., Smith J.M.B., Morwood M. \& Davidson I.D. (eds) Faunal and Floral Migrations and Evolution in SE Asia-Australasia: 35-56. Swets \& Zeitlinger Publishers, Lisse, the Netherlands.

Hall T.E. 1999. BioEdit: a user-friendly biological sequence alignment editor and analysis program for Windows 95/98/NT. Nucleic Acids Symposium Series 41: 95-98.

Isaac N.J.B., Turvey S.T., Collen B., Waterman C. \& Baillie J.E.M. 2007. Mammals on the EDGE: Conservation priorities based on threat and phylogeny. PLOS ONE 2: e296. http://dx.doi.org/10.1371/ journal.pone.0000296

IUCN 2015. The IUCN Red List of Threatened Species 2015. Available from http://www.iucnredlist.org [accessed 04 January 2016].

Jennings A.P. \& Veron G. 2009. Family Viverridae. In: Wilson D. \& Mittermeier R.A. (eds) Handbook of the Mammals of the World, Volume 1, Carnivores: 174-223. Lynx Edicions, Barcelona. 
VERON G. et al., Systematics and biogeography of the Hemigalinae civets

Jennings A.P., Mathai J., Brodie J., Giordano A.J. \& Veron G. 2013. Predicted distributions and conservation status of two threatened Southeast Asian small carnivores: the banded civet and Hose's civet. Mammalia 77: 261-671. http://dx.doi.org/10.1515/mammalia-2012-0110

Librado P. \& Rosas J. 2009. DnaSP v5: a software for comprehensive analysis of DNA polymorphism data. Bioinformatics 25: 1451-1452. http://dx.doi.org/10.1093/bioinformatics/btp187

Masuda R., Kaneko Y., Siriaroonrat B., Subramaniam V. \& Hamachi M. 2008. Genetic variations of the masked palm civet Paguma larvata, inferred from mitochondrial cytochrome $b$ sequences. Mammal Study 33: 19-24. http://dx.doi.org/10.3106/1348-6160(2008)33[19:GVOTMP]2.0.CO;2

Meijaard E. 2003. Mammals of south-east Asian islands and their Late Pleistocene environments. Journal of Biogeography 30: 1245-1257. http://dx.doi.org/10.1046/j.1365-2699.2003.00890.x

Meijaard E. 2009. Solving mammalian riddles along the Indochinese-Sundaic zoogeographic transition: new insights from mammalian biogeography. Journal of Biogeography 36: 801-802. http://dx.doi. org/10.1111/j.1365-2699.2009.02124.x

Meijaard E. \& Sheil D. 2008. The persistence and conservation of Borneo's mammals in lowland rain forests managed for timber: observations, overviews and opportunities. Ecological Research 23: 21-34. http://dx.doi.org/10.1007/s11284-007-0342-7

Moritz C. 1994. Applications of mitochondrial DNA analysis in conservation: a critical review. Molecular Ecology 3: 401-411. http://dx.doi.org/10.1111/j.1365-294X.1994.tb00080.x

Patou M.L., Debruyne R., Jennings A.P., Zubaid A., Rovie-Ryan J.J. \& Veron G. 2008. Phylogenetic relationships of the Asian palm civets (Hemigalinae \& Paradoxurinae, Viverridae, Carnivora). Molecular Phylogenetics and Evolution 47: 883-892. http://dx.doi.org/10.1016/j.ympev.2008.03.026

Patou M.L., Chen J., Cosson L., Andersen D.H., Cruaud C., Couloux A., Randi E., Zhang S. \& Veron G. 2009. Low genetic diversity in the masked palm civet Paguma larvata (Viverridae). Journal of Zoology 278: 218-230. http://dx.doi.org/10.1111/j.1469-7998.2009.00570.x

Patou M.L., Wilting A., Gaubert P., Esselstyn J.A., Cruaud C., Jennings A.P., Fickel J. \& Veron G. 2010. Evolutionary history of the Paradoxurus palm civets - a new model for Asian biogeography. Journal of Biogeography 37: 2077-2097. http://dx.doi.org/10.1111/j.1365-2699.2010.02364.x

Pocock R.I. 1933. The rarer genera of oriental Viverridae. Proceedings of the Zoological Society of London 1933: 969-1035.

Rambaut A. 2012. Figtree Version 1.4.0. Available from http://tree.bio.ed.ac.uk/software/figtree/ [accessed 30 Sep. 2013].

Ronquist F., Teslenko M., Van Der Mark P., Ayres D.L., Darling A., Hohna S., Larget B., Liu L., Suchard M.A. \& Huelsenbeck J.P. 2012. MrBayes 3.2: efficient Bayesian phylogenetic inference and model choice across a large model space. Systematic Biology 61: 539-542. http://dx.doi.org/10.1093/sysbio/ sys029

Ryder O.A. 1986. Species conservation and systematics: the dilemma of subspecies. Trends in Ecology and Evolution 1: 9-10. http://dx.doi.org/10.1016/0169-5347(86)90059-5

Sargis E.J., Woodman N., Morningstar N.C., Reese A.T. \& Olson L.E. 2014. Island history affects faunal composition: the treeshrews (Mammalia: Scandentia: Tupaiidae) from the Mentawai and Batu Islands, Indonesia. Biological Journal of the Linnean Society 111: 290-304. http://dx.doi.org/10.1111/bij.12195

Sathiamurthy E. \& Voris H.K. 2006. Maps of Holocene sea level transgression and submerged lakes on the Sunda Shelf. The Natural History Journal of Chulalongkorn University Suppl. 2: 1-43. 
Sato J., Hosoda T., Wolsan M., Tsuchiya K., Yamamoto M. \& Suzuki H. 2003. Phylogenetic relationships and divergence times among mustelids (Mammalia: Carnivora) based on nucleotide sequences on the nuclear interphotoreceptor retinoid binding protein and mitochondrial cytochrome $b$ genes. Zoological Science 20: 243-264. http://dx.doi.org/10.2108/zsj.20.243

Schreiber A., Wirth R., Riffel M. \& Van Rompaey H. 1989. Weasels, Civets and Mongooses, and their Relatives. An Action Plan for the Conservation of Mustelids and Viverrids. IUCN/SSC Mustelid and Viverrid Specialist Group, Gland.

Shekelle M., Meier R., Wahyu I., Wirdateti \& Ting N. 2010. Molecular phylogenetics and chronometrics of Tarsiidae based on 12S mtDNA haplotypes: Evidence for Miocene origins of crown tarsiers and numerous species within the Sulawesian clade. International Journal of Primatology 31: 1083-1106. http://dx.doi.org/10.1007/s10764-010-9457-8

Simmons M.P. 2012. Radical instability and spurious branch support by likelihood when applied to matrices with non-random distributions of missing data. Molecular Phylogenetics and Evolution 62: 472-484. http://dx.doi.org/10.1016/j.ympev.2011.10.017

Stelbrink B., Albrecht C., Hall R. \& Von Rintelen T. 2012. The biogeography of Sulawesi revisited: Is there evidence for a vicariant origin of taxa on Wallace's "anomalous island"? Evolution 66: 2252-2271. http://dx.doi.org/10.1111/j.1558-5646.2012.01588.x

Tamura K., Stecher G., Peterson D., Filipski A. \& Kumar S. 2013. MEGA6: Molecular Evolutionary Genetics Analysis version 6.0. Molecular Biology and Evolution 30: 2725-2729. http://dx.doi. org $/ 10.1093 / \mathrm{molbev} / \mathrm{mst} 197$

Tu V.T., Csorba G., Ruedi M., Furey N.M., Son N.T., Thong V.D., Bonillo C. \& Hassanin A. 2017. Comparative phylogeography of bamboo bats of the genus Tylonycteris (Chiroptera, Vespertilionidae) in Southeast Asia. European Journal of Taxonomy 274: 1-38. http://dx.doi.org/10.5852/ejt.2017.274

Veron G. 1994. Méthodes de Recherche en Biotaxonomie des Mammifères Carnivores. Confrontation des Méthodes de Phylogénie Traditionnelle et Moléculaire dans la Recherche de la Position Systématique de Cryptoprocta ferox (Aeluroidea). PhD Dissertation, Muséum national d'Histoire naturelle, France.

Veron G. 1995. La position systématique de Cryptoprocta ferox (Carnivora). Analyse cladistique des caractères morphologiques de carnivores Aeluroidea actuels et fossiles. Mammalia 59: 551-582. http:// dx.doi.org/10.1515/mamm.1995.59.4.551

Veron G. 2001. The palm civets of Sulawesi. Small Carnivore Conservation 24: 13-14.

Veron G. 2010. Phylogeny of the Viverridae and 'viverrid-like' feliforms. In: Goswami A. \& Friscia A. (eds) Carnivoran Evolution. New Views on Phylogeny, Form and Function: 64-91. Cambridge University Press, Cambridge.

Veron G. \& Heard S. 2000. Molecular systematics of the Asiatic Viverridae (Carnivora) inferred from mitochondrial cytochrome $b$ sequence analysis. Journal of Zoological Systematics and Evolutionary Research 38: 209-217. http://dx.doi.org/10.1046/j.1439-0469.2000.384132.x

Veron G., Heard Rosenthal S., Long B. \& Roberton S. 2004. The molecular systematics and conservation of an endangered carnivore, the Owston's palm civet Chrotogale owstoni (Thomas, 1912) (Carnivora, Viverridae, Hemigalinae). Animal Conservation 7: 107-112. http://dx.doi.org/10.1017/ $\underline{\mathrm{S} 1367943003001136}$

Veron G., Gaubert P., Franklin N., Jennings A.P. \& Grassman Jr L.I. 2006. A reassessment of the distribution and taxonomy of the endangered otter civet Cynogale bennettii (Carnivora: Viverridae) of South-east Asia. Oryx 40: 42-49. 
VERON G. et al., Systematics and biogeography of the Hemigalinae civets

Veron G., Patou M.L., Pothet G., Simberloff D. \& Jennings A.P.J. 2007. Systematic status and biogeography of the Javan and small Indian mongooses (Herpestidae, Carnivora). Zoologica Scripta 36: 1-10. http://dx.doi.org/10.1111/j.1463-6409.2006.00261.x

Veron G., Willsch M., Dacosta V., Patou M.L., Seymour A., Bonillo C., Couloux A., Wong S.T., Jennings A.P., Fickel J. \& Wilting A. 2014. The distribution of the Malay civet Viverra tangalunga (Carnivora: Viverridae) across Southeast Asia: natural or human-mediated dispersal? Zoological Journal of the Linnean Society 170: 917-932. http://dx.doi.org/10.1111/zoj.12110

Veron G., Patou M.L., Debruyne R., Couloux A., Fernandez D.A.P., Wong S.T., Fuchs J. \& Jennings A.P. 2015a. Systematics of the Southeast Asian mongooses (Herpestidae, Carnivora): Solving the mystery of the elusive collared mongoose and Palawan mongoose. Zoological Journal of the Linnean Society 173: 236-248. http://dx.doi.org/10.1111/zoj.12206

Veron G., Patou M.L. \& Jennings A.P. 2015b. Molecular systematics of the small-toothed palm civet (Arctogalidia trivirgata) reveals a strong divergence of Borneo populations. Mammalian Biology 80: 347-354. http://dx.doi.org/10.1016/j.mambio.2015.02.003

Veron G., Patou M.L., Tóth M., Goonatilake M. \& Jennings A.P. 2015c. How many species of Paradoxurus civets are there? New insights from India and Sri Lanka. Journal of Zoological Systematics and Evolutionary Research 53: 161-174. http://dx.doi.org/10.1111/jzs.12085

Voris H.K. 2000. Maps of Pleistocene sea levels in Southeast Asia: shorelines, river systems and time durations. Journal of Biogeography 27: 1153-1167. http://dx.doi.org/10.1046/j.1365-2699.2000.00489.x

Willcox D., Do T.H. \& Tran Q.P. 2011. Report on the winter-spring survey for small carnivores and pangolins in the Ngoc Son - Ngo Luong Nature Reserve, Hoa Binh Province, Carnivore and Pangolin Conservation Program, Vietnam. Available from http://www.savevietnamswildlife.org/publications/ [accessed 28 Jan. 2015].

Wilting A. \& Fickel J. 2012. Phylogenetic relationship of two threatened endemic viverrids from the Sunda Islands, Hose's civet and Sulawesi civet. Journal of Zoology 288: 184-190. http://dx.doi. org/10.1111/j.1469-7998.2012.00939.x

Wilting A., Sollmann R., Meijaard E., Helgen K.M. \& Fickel J. 2012. Mentawai's endemic, relictual fauna: is it evidence for Pleistocene extinctions on Sumatra? Journal of Biogeography 39: 1608-1620. http://dx.doi.org/10.1111/j.1365-2699.2012.02717.x

Winnepenninckx B., Backeljau T. \& De Wachter R. 1993. Extraction of high molecular weight DNA from molluscs. Trends in Genetics 9: 407. http://dx.doi.org/10.1016/0168-9525(93)90102-N

Woodruff D.S. 2010. Biogeography and conservation in Southeast Asia: how 2.7 million years of repeated environmental fluctuations affect today's patterns and the future of the remaining refugialphase biodiversity. Biodiversity and Conservation 19: 919-941. http://dx.doi.org/10.1007/s10531-010$\underline{9783-3}$

Woodruff D.S. \& Turner L. 2009. The Indochinese-Sundaic zoogeographic transition: a description and analysis of terrestrial mammal species distributions. Journal of Biogeography 36: 803-821. http:// dx.doi.org/10.1111/j.1365-2699.2008.02071.x

Wozencraft C.W. 1989. The phylogeny of the recent Carnivora. In: Gittleman J.L. (ed.) Carnivores: Behavior, Ecology, and Evolution: 495-535. Cornell University Press, Ithaca, New York.

Wozencraft C.W. 2005. Order Carnivora. In: Wilson D.E. \& Reeder D.M. (eds) Mammal Species of the World. A Taxonomic and Geographic Reference, $3^{\text {rd }}$ edition: 532-628. The Johns Hopkins University Press, Baltimore. 
Yoder A.D., Burns M.M., Zehr S., Delefosse T., Veron G., Goodman S.M. \& Flynn J.J. 2003. Single origin of Malagasy Carnivora from an African ancestor. Nature 421: 734-737. http://dx.doi.org/10.1038/ $\underline{\text { nature } 01303}$

Yu L. \& Zhang Y.P. 2005. Phylogenetic studies of pantherine cats (Felidae) based on multiple genes, with novel application of nuclear $\beta$-fibrinogen intron 7 to carnivores. Molecular Phylogenetics and Evolution 35: 483-495. http://dx.doi.org/10.1016/j.ympev.2005.01.017

Yu L., Li Q.W., Ryder O.A. \& Zhang Y.P. 2004. Phylogenetic relationships within mammalian order Carnivora indicated by sequences of two nuclear DNA genes. Molecular Phylogenetics and Evolution 33: 694-705. http://dx.doi.org/10.1016/j.ympev.2004.08.001

Manuscript received: 16 February 2016

Manuscript accepted: 5 September 2016

Published on: 23 February 2017

Guest editors: Line Le Gall, Frédéric Delsuc, Stéphane Hourdez, Guillaume Lecointre

and Jean-Yves Rasplus

Desk editor: Danny Eibye-Jacobsen

Printed versions of all papers are also deposited in the libraries of the institutes that are members of the EJT consortium: Muséum national d'Histoire naturelle, Paris, France; Botanic Garden Meise, Belgium; Royal Museum for Central Africa, Tervuren, Belgium; Natural History Museum, London, United Kingdom; Royal Belgian Institute of Natural Sciences, Brussels, Belgium; Natural History Museum of Denmark, Copenhagen, Denmark; Naturalis Biodiversity Center, Leiden, the Netherlands. 